\title{
First pass metabolism of ethanol is strikingly influenced by the speed of gastric emptying
} C M Oneta, U A Simanowski, M Martinez, A Allali-Hassani, X Parés, N Homann,
C Conradt, R Waldherr, W Fiehn, C Coutelle, H K Seitz
Laboratory of Alcohol Research, Liver Disease and Nutrition, Department of Medicine, Salem Medical Center, Heidelberg, Germany C M Oneta U A Simanowski M Martinez

N Homann

H K Seitz

Departments of Clinical Chemistry, Biostatistics and Pathology, University of Heidelberg, Heidelberg, Germany C Conradt $\mathrm{R}$ Waldherr

W Fiehn

Department of

Biochemistry and Molecular Biology, Autonomous

University of Barcelona, Bellaterra, Spain

A Allali-Hassani

$\mathrm{X}$ Parés

Department of Biochemistry and Molecular Biology, University of Bordeaux, Bordeaux, France

C Coutelle

Correspondence to: Dr H K Seitz, Laboratory of Alcohol Research, Liver Disease and Nutrition, Department of Medicine, Salem Medical Center, Zeppelinstraße 11-33, 69121 Heidelberg, Germany.

Accepted for publication 13 May 1998

\begin{abstract}
Background-Ethanol undergoes a first pass metabolism (FPM) in the stomach and liver. Gastric FPM of ethanol primarily depends on the activity of gastric alcohol dehydrogenase (ADH). In addition, the speed of gastric emptying (GE) may modulate both gastric and hepatic FPM of ethanol.

Aims-To study the effect of modulation of GE on FPM of ethanol in the stomach and liver.

Methods-Sixteen volunteers (eight men and eight women) received ethanol $(0.225$ g/kg body weight) orally and intravenously, and the areas under the ethanol concentration time curves were determined to calculate FPM of ethanol. In seven of these subjects, FPM of ethanol was measured after the intravenous administration of $\mathbf{1 0}$ mg metoclopramide (MCP) and $20 \mathrm{mg}$ $\mathrm{N}$-butylscopolamine (NBS) in separate experiments to either accelerate or delay GE. GE was monitored sonographically by integration of the antral area of the stomach every five minutes for 90 minutes after oral ethanol intake. In addition, gastric biopsy specimens were taken to determine ADH activity and phenotype, as well as to evaluate gastric histology. Blood was also drawn for ADH genotyping.

Results-GE time was significantly delayed by the administration of NBS as compared with controls $(p<0.0001)$ and as compared with the administration of MCP $(p<0.0001)$. This was associated with a significantly enhanced FPM of ethanol with NBS compared with MCP ( $p=$ 0.0004). A significant correlation was noted between GE time and FPM of ethanol $(r=0.43, p=0.0407)$. Gastric ADH activity did not significantly correlate with FPM of ethanol.

Conclusion-FPM of ethanol is strikingly modulated by the speed of GE. Delayed GE increases the time of exposure of ethanol to gastric ADH and may therefore increase gastric FPM of ethanol. In addition, hepatic FPM of ethanol may also be enhanced as the result of slower absorption of ethanol from the small intestine. Thus a knowledge of GE time is a major prerequisite for studying FPM of ethanol in humans.

(Gut 1998;43:612-619)
\end{abstract}

Keywords: first pass metabolism of ethanol; gastric emptying; alcohol dehydrogenase; ethanol metabolism; stomach
Oral alcohol ingestion results in lower blood ethanol concentrations than are observed after the intravenous administration of an equal amount of ethanol. This phenomenon is called first pass metabolism (FPM) of ethanol, which is due, at least in part, to gastric ethanol metabolism by alcohol dehydrogenase (ADH). In the stomach various $\mathrm{ADH}$ isoenzymes, including class I $(\beta, \gamma)$, III $(\chi)$ and IV $(\sigma)$, exist. ${ }^{12}$ All of these ADH isoenzymes contribute to ethanol metabolism after oral alcohol intake ${ }^{2-6}$, and, as they have different kinetic properties, total gastric $\mathrm{ADH}$ activity varies with the ethanol concentration of the alcohol beverage consumed. Although a significant correlation between gastric ADH activity and FPM of ethanol has been shown, ${ }^{3}$ the contribution of the stomach to FPM of ethanol still remains a matter of debate, as it has been suggested that hepatic FPM of ethanol also exists, which may be influenced by, among other factors, the speed of alcohol absorption. ${ }^{7-10}$

It has been shown that gastric $\mathrm{ADH}$ activity is affected by various factors including gender, ${ }^{3511-13}$ age, ${ }^{251112}$ medication, ${ }^{14-18}$ concentration of ingested ethanol, ${ }^{19}{ }^{20}$ and gastric morphology, including atrophic gastritis and the presence of Helicobacter pylori. ${ }^{21-26}$ In addition, the pattern of $\mathrm{ADH}$ isozyme expression in the gastric mucosa also determines $\mathrm{ADH}$ activity. Thus the presence of $\sigma-\mathrm{ADH}$ and $\mathrm{ADH}_{3}{ }^{1-1}$ is associated with high total gastric $\mathrm{ADH}$ activity. It is interesting to note that fasting and gastrectomy significantly decrease FPM of ethanol, ${ }^{27}{ }^{28}$ possibly because of more rapid gastric emptying (GE) and an increased rate of intestinal absorption of ethanol. An increased speed of GE may both decrease the time of exposure of ethanol to gastric $\mathrm{ADH}$, reducing gastric FPM of ethanol, and lead to accelerated absorption of ethanol, which may decrease hepatic FPM of alcohol. ${ }^{8}$ Indeed, recently Pedrosa $e t a l^{4}$ found a significant association between FPM of ethanol and GE time, and Amir et $a l^{18}$ reported increased bioavailability of imbibed alcohol when administered in combination with the $\mathrm{H}_{2}$ blocker ranitidine because of the ranitidine induced increase in the rate of GE.

Therefore the aim of our study was to investigate the role of GE and gastric $\mathrm{ADH}$ activity in the FPM of ethanol in healthy volunteers.

\section{Methods}

FIRST PASS EXPERIMENTS

Sixteen volunteers (eight men and eight women) aged between 24 and 52 years (mean (SEM) age 37.1 (2.0) years; mean age of 

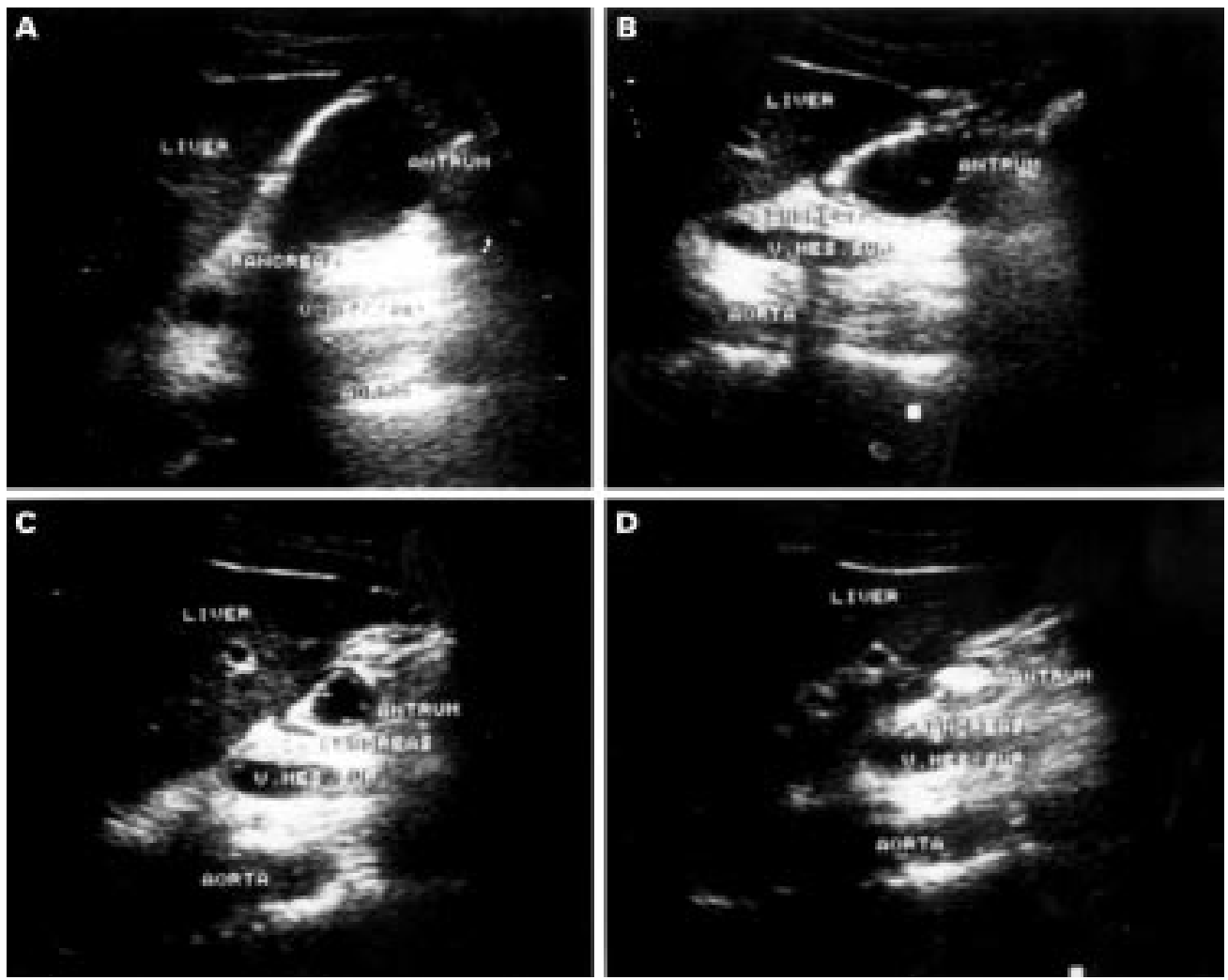

Figure 1 Sonograph of the antrum of the stomach during gastric emptying without medication. The integral antral area decreases with time. A, After five minutes; B, after 30 minutes; $C$, after 60 minutes; D, after 90 minutes.

women 35.6 (3.3), range $24-52$ years; mean age of men $38.5(2.2)$, range $2-45$ years) were studied. One hour after a standard breakfast (consisting of one slice of bread with butter and marmalade and one cup of coffee with milk and sugar) each volunteer received ethanol $(0.225 \mathrm{~g} / \mathrm{kg}$ body weight) orally on day 1 and intravenously on day 2 . Ethanol was given as a $5 \mathrm{~g} / 100 \mathrm{ml}$ concentration in a $5 \%$ glucose solution and administered orally within two minutes and intravenously as a continuous infusion over 30 minutes. Blood samples $(3 \mathrm{ml})$ were drawn at time 0 and after $5,10,15,20,30$, $45,60,90,120,150,180,210$, and 240 minutes through an intravenous catheter, and serum was obtained for the determination of

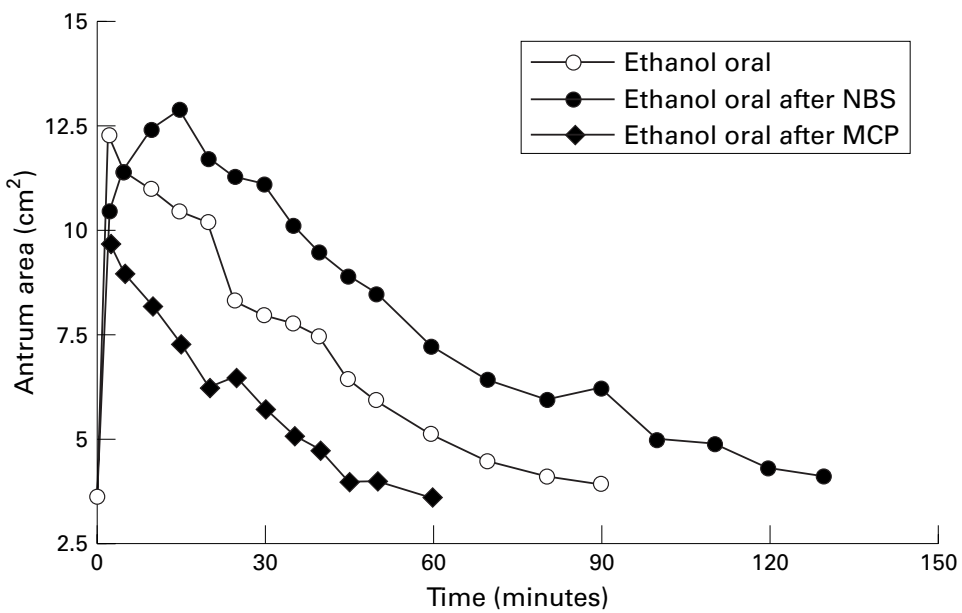

Figure 2 Monitoring of gastric emptying of one subject after oral ethanol intake with metoclopramide (MCP), N-butylscopolamine (NBS), and without medication. ethanol concentration. ${ }^{24}$ To modulate the speed of GE, the above experiment was repeated in ten volunteers (six men and four women) with the modification that $10 \mathrm{mg}$ metoclopramide (MCP) was given intravenously three minutes before oral alcohol administration on day 3 and $20 \mathrm{mg}$ $\mathrm{N}$-butylscopolamine (NBS) on day 4 . In seven of these volunteers (four men and three women), the same experiment was repeated, when alcohol was administered intravenously (days 5 and 6). Plasma ethanol concentrations were measured using an adaptation of an assay developed by Sigma Diagnostics (Procedure No 322; St Louis, Missouri, USA) for a Cobas Fara II Centrifugal Analyzer (Roche Analytical Instruments Inc, Nutley, New Jersey, USA). This adaptation of an enzymic method developed by Bucher \& Redeteski ${ }^{29}$ included the dilution of the lowest standard to accommodate low levels of plasma ethanol. The area under the whole blood concentration time curve (AUC) was calculated by applying the trapezoidal rule, with extrapolation from the last measured concentration to infinity by use of the final slope. FPM was calculated from the differences between the AUC values from the concomitant intravenous and oral alcohol administration. The study was approved by the ethics committee of the University of Heidelberg, and each participant gave written consent.

MEASUREMENT OF GE

To monitor the speed of GE, a sonographic method was used to determine the antral area 

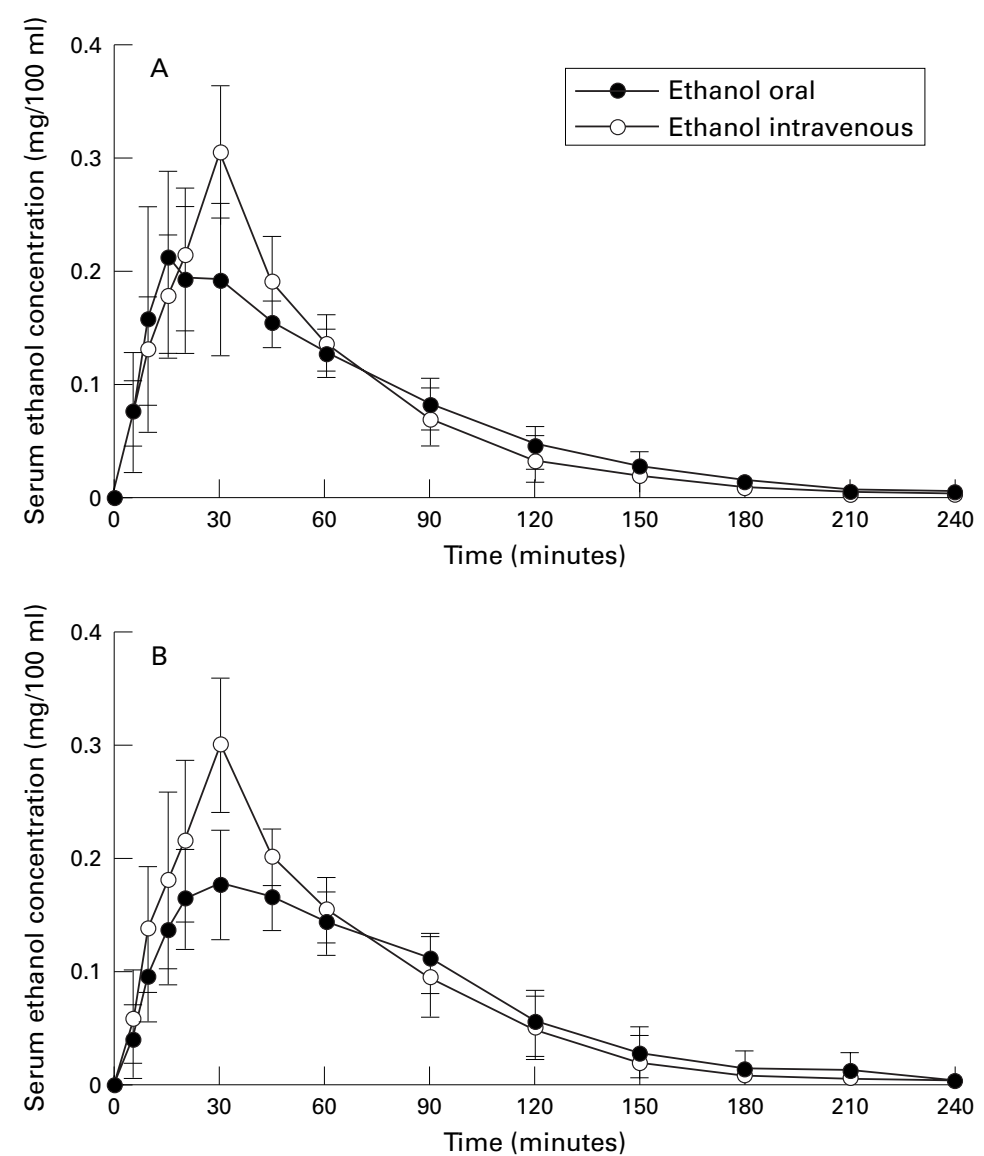

Figure 3 Serum ethanol concentration time curves without medication after oral and intravenous ethanol administration $(A)$ for men $(n=8)$ and $(B)$ for women $(n=8)$. No significant differences are noted between men and women.

of the stomach after ethanol ingestion with and without preceding application of MCP and NBS. ${ }^{30} 31$ The reduction in the antral area was measured with time (every five minutes for 90 minutes) and complete GE was reached when the antral area was similar to that measured before alcohol administration. This method has previously been validated by barium $x$ ray of the stomach ${ }^{30}$ and by scintigraphy. ${ }^{31}$ Figure 1 shows the typical sonographic appearance of the antrum of the stomach during GE, and, as an example, fig 2 shows the monitoring of GE

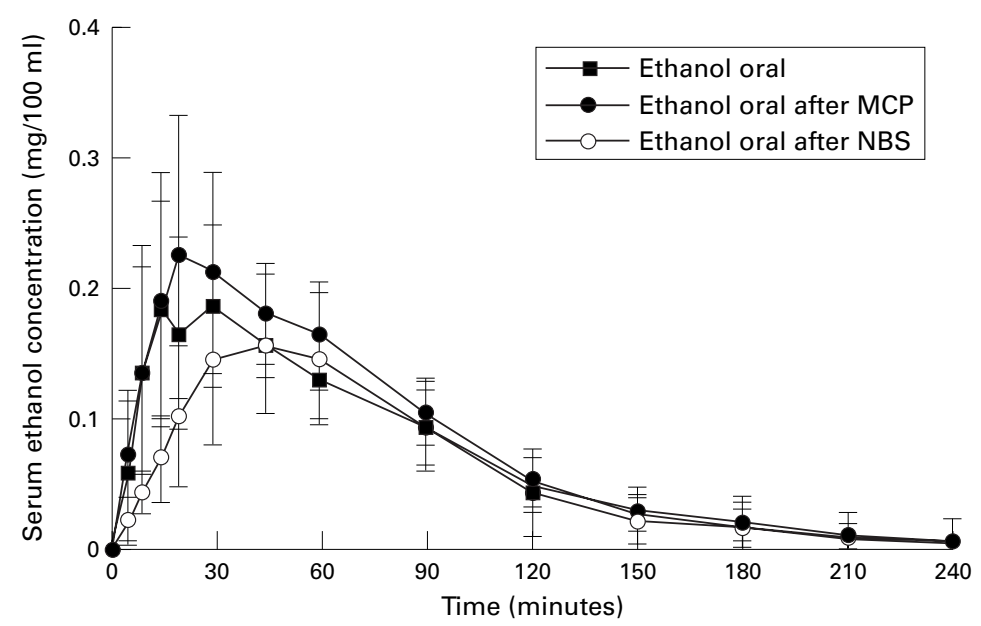

Figure 4 Serum ethanol concentration time curves after oral alcohol ingestion $(n=10)$ without medication, with metoclopramide (MCP), or with N-butylscopolamine (NBS). of one subject after oral ethanol administration without and with prior intravenous injection of MCP and NBS.

\section{GASTROSCOPY}

At the end of the first-pass experiments all volunteers except two, who refused, underwent gastroscopy $(\mathrm{n}=14)$, and biopsy specimens were taken from the antrum and body of the stomach to determine gastric $\mathrm{ADH}$ activity and to assess gastric mucosal histology and the presence or absence of $H$ pylori. None of the volunteers was receiving medication-for example, $\mathrm{H}_{2}$ receptor blockers or aspirin. Endoscopy was carried out with an Olympus GIF Q10 endoscope (Olympus, Hamburg, Germany), and the biopsy specimens were obtained with a forceps type FB3K (Olympus).

ASSAY OF ADH ACTIVITY

$\mathrm{ADH}$ activity was measured as previously described. ${ }^{25}$ The biopsy specimens (wet weight 5-12 mg) were immediately frozen in liquid nitrogen and kept at $-80^{\circ} \mathrm{C}$ until assayed. The tissue specimens were homogenised in $20 \mathrm{mM}$ Tris/ $\mathrm{HCl}$ buffer $(\mathrm{pH} 8.6)$ at $4^{\circ} \mathrm{C}$ using a specially designed homogeniser for Eppendorf vials (VWR Inc, Andover, Massachusetts, USA), and then centrifuged at $3000 \mathrm{rpm}$ for one minute. The supernatant was used for assay of $\mathrm{ADH}$ activity. $\mathrm{ADH}$ activity was determined by monitoring the formation of $\mathrm{NADH}$ at $340 \mathrm{~nm}$ and $25^{\circ} \mathrm{C}$ in a Cary 219 spectrophotometer. Alcohol oxidation was measured in a 1 $\mathrm{ml} / \mathrm{cm}$ light path cell with $0.1 \mathrm{M}$ glycine/ $\mathrm{NaOH}, \mathrm{pH}$ 10.0. The $\mathrm{NAD}^{+}$concentration used was $2.4 \mathrm{mM}$ and the ethanol concentration $100 \mathrm{mM}$. The soluble protein content in the supernatant fraction was measured by the method of Lowry et $a b^{32}$ using bovine serum albumin as standard.

\section{PHENOTYPING OF ADH}

To determine the isoenzymes of $\mathrm{ADH}$, starch gel electrophoresis was performed on gastric biopsy samples as described by Moreno and Parés. ${ }^{4}$ The gels $(24 \times 12 \times 0.3 \mathrm{~cm})$ contained $11 \%$ starch, $0.74 \mathrm{mM} \mathrm{NAD}^{+}$, and $20 \mathrm{mM}$ Tris/HCl, $\mathrm{pH}$ 8.6. Samples were applied to paper wicks $(6 \times 3 \times 0.25 \mathrm{~mm})$ and inserted into the gel at the centre of the slabs. Gels were run at $720 \mathrm{~V}$ for five hours at $4^{\circ} \mathrm{C}$. Immediately after electrophoresis, gels were sliced longitudinally into two slabs, which were stained for $\mathrm{ADH}$ activity. The staining solution $(500 \mathrm{ml})$ contained $50 \mathrm{mM}$ Tris/ $\mathrm{HCl}, \mathrm{pH} 8.6,100 \mathrm{mM}$ 2-buten-1-ol, $11 \mathrm{mM}$ pyruvic acid, $0.55 \mathrm{mM}$ $\mathrm{NAD}^{+}, 0.24 \mathrm{mM}$ nitro blue tetrazolium, and $0.065 \mathrm{mM}$ phenazine methosulphate. Gel slabs were incubated in these solutions at $40^{\circ} \mathrm{C}$ for about 40 minutes in the dark. After being stained, the gels were washed with water, photographed, and stored at $4^{\circ} \mathrm{C}$.

GENOTYPING OF ADH

Drops of blood were taken from each subject by finger prick, deposited on to filter paper, and used for determination of $\mathrm{ADH}_{3}$ genotypes. $\mathrm{ADH}_{3}$ genotyping was carried out by polymerase chain reaction (PCR) amplification. ${ }^{33}$ A 5 


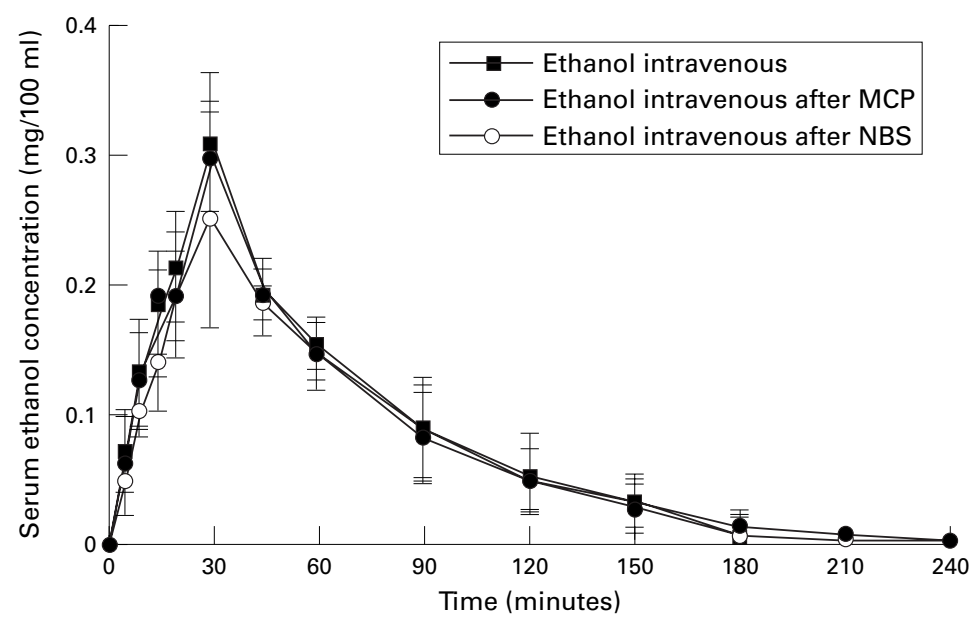

Figure 5 Serum ethanol concentration time curves after intravenous administration $(n=$ 7) without medication, with metoclopramide (MCP), or with N-butylscopolamine (NBS).

mm disk of filter paper impregnated with dry blood was placed directly into $100 \mathrm{ml} \mathrm{PCR}$ buffer (0.01 M Tris/HCl, $0.05 \mathrm{M} \mathrm{KCl,} 0.0015$ $\mathrm{M} \mathrm{MgCl}_{2}, 0.1 \%$ Triton X-100, $\mathrm{pH}$ 8.8) together with the deoxyribonucleoside triphosphates dATP, dCTP, dGTP, and dTTP, as well as two oligonucleotide primers each at $1 \mathrm{mM}$. The primers for $\mathrm{ADH}_{3}$ were those described by Groppi et al. ${ }^{34}$

Genomic DNA was denatured at $92^{\circ} \mathrm{C}$ for 10 minutes. The thermostable DNA polymer-
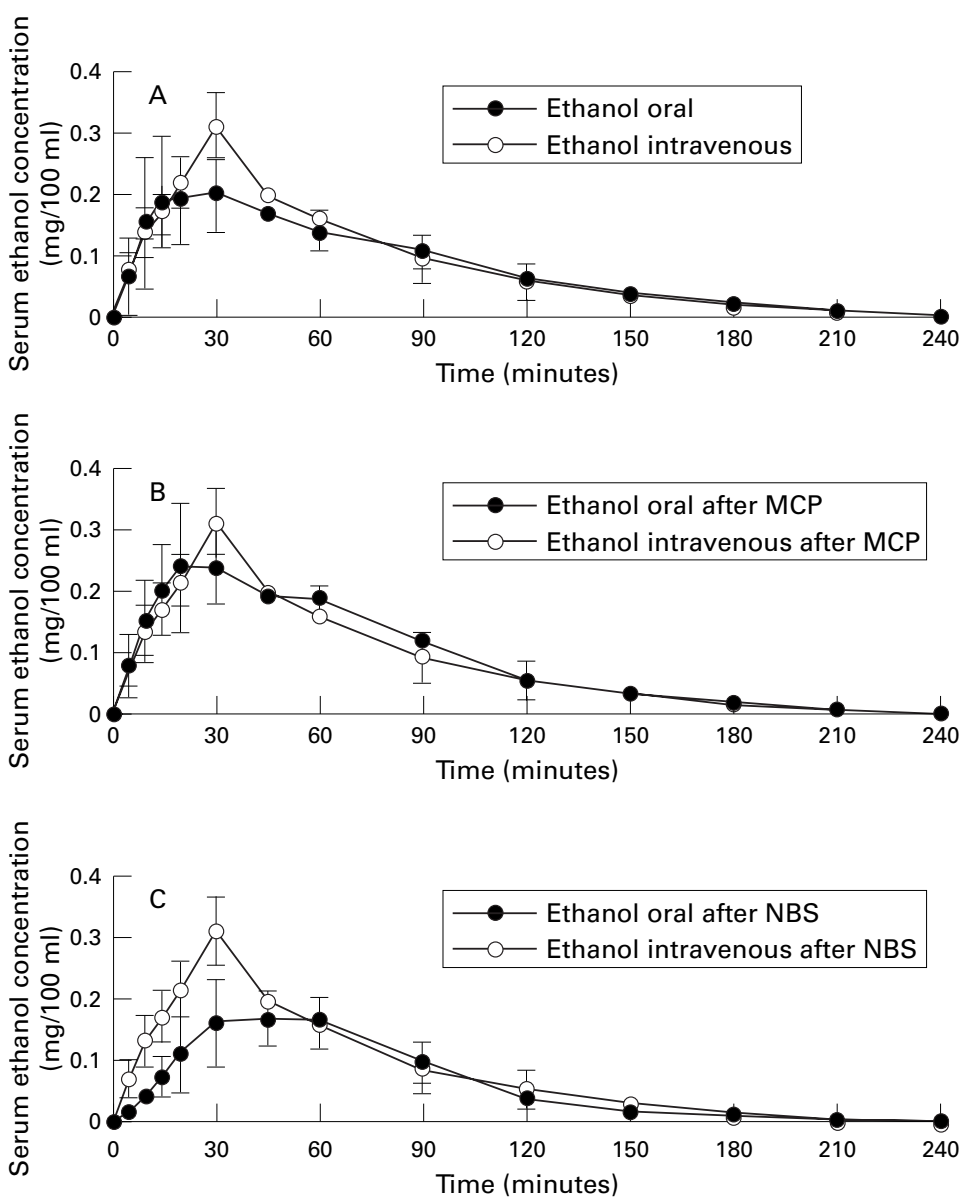

Figure 6 Serum ethanol concentration time curves after intravenous ethanol administration and after ethanol ingestion (A) without medication, (B) after metoclopramide $(M C P)$, or $(C)$ after $N$-butylscopolamine $(N B S)(n=7)$. ase extracted from Thermus brockianus was then added $(2.5 \mathrm{U}$ per $100 \mathrm{ml})$. Thirty five cycles were carried out, each comprising denaturation for one minute at $92^{\circ} \mathrm{C}$, annealing for one minute at $55^{\circ} \mathrm{C}$, and extension for two minutes at $72^{\circ} \mathrm{C}$.

For $\mathrm{ADH}_{3}$ genotyping, the PCR mixture was directly digested using the restriction enzyme $S s p$ I. Another site for $S s p$ I was created by directed mutagenesis, as an internal digestion control. ${ }^{34}$ The fragments were separated using high voltage vertical polyacrylamide gel electrophoresis. The $\mathrm{ADH}_{3}{ }^{1}$ allele was characterised by the presence of fragments of 67 and 63 $\mathrm{bp}$, whereas the $\mathrm{ADH}_{3}{ }^{2}$ allele was characterised by a single $130 \mathrm{bp}$ fragment. The bands were visualised in a bath of ethidium bromide and photographed under UV light.

\section{HISTOLOGY}

Histological sections of gastric biopsy specimens were stained with haematoxylin and eosin, periodic acid/Schiff, and the WarthinStarry method. To assess the severity of gastric mucosal injury, the Sydney System for classification of gastritis in antral biopsy samples was used by a pathologist in a blind fashion. ${ }^{35} \mathrm{~A}$ three graded score system of mild, moderate, and severe was chosen represented by the numbers 1, 2, and 3 respectively. The individual scores were added to obtain a total score representing the degree of inflammation (total range $1-6)$. The graded variables were degree of inflammation and inflammatory activitythat is, the presence of $H$ pylori assessed by the Warthin-Starry method. The total histological score was obtained by adding the individual scores.

IN VITRO STUDIES

To rule out any effect of MCP and NBS on gastric $\mathrm{ADH}$, its activity was determined in the presence and absence of various concentrations of these drugs using human gastric cytosol. Cytosol was prepared from a human stomach specimen obtained from surgery. ${ }^{15}$ The mucosa of histologically normal tissue was scraped off with the edge of a glass slide. All procedures were carried out at $4^{\circ} \mathrm{C}$. The tissue was homogenised $(1: 4, \mathrm{w} / \mathrm{v})$ in $100 \mathrm{mM}$ potassium phosphate buffer ( $\mathrm{pH} 7.4$ ) in a Potter/ Elvehjem homogeniser. After centrifugation at $9000 \mathrm{~g}$ for 20 minutes, the supernatant was centrifuged at $100000 \mathrm{~g}$ for 60 minutes to obtain the cytosol. ADH activity was measured by monitoring the production of NADH at 340 $\mathrm{nm}$ at $\mathrm{pH} 7.4$ at ethanol concentrations of 100 $\mathrm{mM}$ and at $\mathrm{NAD}^{+}$concentrations of $2.4 \mathrm{mM}$ at $22^{\circ} \mathrm{C}$. Measurements were performed at various concentrations of MCP and NBS (as shown in fig 8). The soluble protein content of the supernatant fraction was measured by the method of Lowry et $a l^{32}$ using bovine serum albumin as standard.

STATISTICAL ANALYSIS

Data in the tables and text are presented as mean (SEM). FPM of ethanol was analysed using paired Student's $t$ test. The relation between FPM of ethanol and the speed of GE 
Table 1 Peak serum ethanol concentrations and time of peak serum ethanol concentrations without additional medication and following metoclopramide (MCP) or N-butylscopolamine (NBS) administration $(n=7)$

\begin{tabular}{|c|c|c|c|c|c|c|c|c|c|c|c|}
\hline \multicolumn{6}{|c|}{ Peak serum ethanol concentration $(\mathrm{mg} / 100 \mathrm{ml})$} & \multicolumn{6}{|c|}{ Time of peak serum ethanol concentration (min) } \\
\hline \multicolumn{3}{|l|}{ Intravenous } & \multicolumn{3}{|l|}{ Oral } & \multicolumn{3}{|l|}{ Intravenous } & \multicolumn{3}{|l|}{ Oral } \\
\hline- & $M C P$ & NBS & - & $M C P$ & NBS & - & $M C P$ & NBS & - & $M C P$ & $N B S$ \\
\hline $0.31(0.05)$ & $0.30(0.04)$ & $0.27(0.07)$ & $0.23(0.08)$ & $0.27(0.08)$ & $0.21(0.06)$ & $30.0(0.0)$ & $30.0(0.0)$ & $34.3(6.8)$ & $22.9(11.6)$ & $29.3(13.7)$ & $50.0(21.2)$ \\
\hline
\end{tabular}

Results are expressed as mean (SEM).

Significant differences in peak serum ethanol concentrations were as follows: $\mathrm{MCP}_{\text {oral }} v \mathrm{NBS}_{\text {oral }}, \mathrm{p}=0.0233 ; \mathrm{NBS}_{\text {oral }} v$ control $\mathrm{l}_{\text {intravenous }}, \mathrm{p}=0.0356$.

Significant differences in the time of peak serum ethanol concentrations were as follows: $\mathrm{NBS}_{\text {oral }} v$ control $_{\text {oral }}, \mathrm{p}=0.0371 ; \mathrm{MCP}_{\text {oral }} v \mathrm{NBS}$ oral, $\mathrm{p}=0.0356$.

Table 2 Speed of gastric emptying after oral ethanol intake without additional medication and in the presence of metoclopramide (MCP) or N-butylscopolamine (NBS) $(n=9)$

\begin{tabular}{lll}
\hline $\begin{array}{l}\text { Ethanol } \\
\text { administration }\end{array}$ & Speed of GE (min) & $\begin{array}{l}\text { Statistical } \\
\text { significance }\end{array}$ \\
\hline $\begin{array}{lll}\text { Alone (I) } \\
+ \text { MCP (II) }\end{array}$ & $44.1(3.1)$ & (I) $v$ (II) $\mathrm{p}=0.0006$ \\
(II) $v$ (III) \\
+NBS (III) & $70.6(2.8)$ & $\begin{array}{l}\text { (III) } v \text { (II) } \\
\mathrm{p}=0.0001\end{array}$ \\
\hline
\end{tabular}

Results are expressed as mean (SEM).

was measured by Pearson's product-moment correlation coefficient and analysis of covariance. $p$ values of 0.05 or less were considered to indicate statistical significance.

\section{Results}

Figure 3 shows serum ethanol concentrations after oral and intravenous ethanol application in eight male (A) and eight female (B) volunteers. The systemic bioavailability of ethanol after oral and intravenous alcohol application was not significantly different in men and women $(p=0.6194)$. The FPM of ethanol in all subjects was $6.5(6.7) \%$. There was no significant difference in FPM between men and women (4.0 (10.0)\% v $8.9(9.4) \%$, p $=0.7080)$. Figure 4 shows serum ethanol concentrations in ten volunteers after oral intake of alcohol without any additional drugs, or with
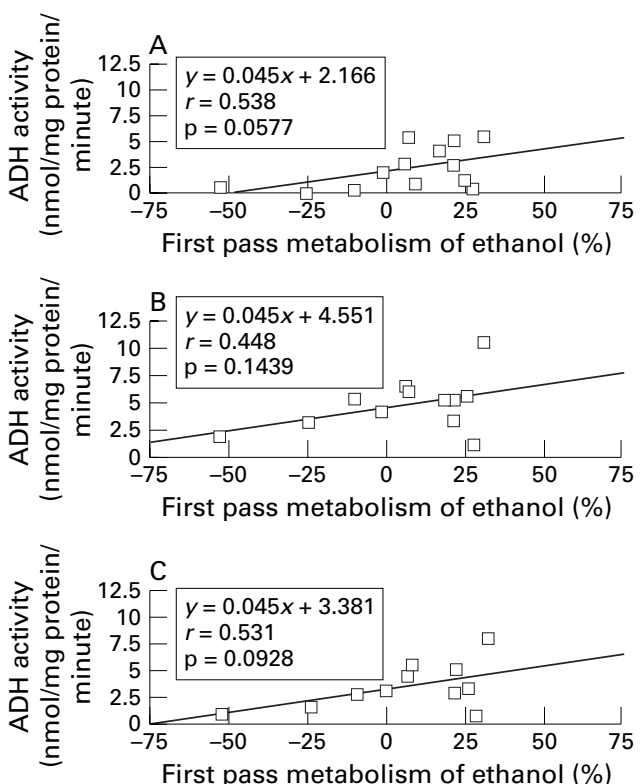

Figure 7 Correlation of first pass metabolism of ethanol with gastric alcohol dehydrogenase $(A D H)$ activity. (A) In the antrum $(n=13) ;(B)$ in the corpus $(n=12) ;(C)$ mean of antrum and corpus $(n=11)$.
$10 \mathrm{mg}$ MCP or $20 \mathrm{mg}$ NBS. The bioavailability of ethanol after oral intake was significantly altered by these medications, being highest with MCP and lowest with NBS (no medication $v$ MCP: $\mathrm{p}=0.0158$; no medication $v$ NBS: $p=0.0425 ;$ MCP $v$ NBS: $p=0.0097)$. In fig 5 the AUC was also measured in seven volunteers when ethanol was given intravenously in the presence or absence of the two drugs. No significant difference in the systemic availability of alcohol was observed after the administration of these drugs. Figure 6 separately shows serum ethanol concentration time curves of seven volunteers after oral ethanol ingestion without medication or after $10 \mathrm{mg}$ MCP or $20 \mathrm{mg}$ NBS in comparison with the corresponding intravenous serum ethanol concentration time curve. FPM of ethanol after NBS was significantly increased as compared with after MCP ( $\mathrm{p}=0.0004)$, and it just missed statistical significance when compared with the FPM of ethanol without additional medication $(p=0.0525)$. No statistical significance was noted when MCP was compared with controls $(p=0.4154)$.

As shown in table 1, highest peak ethanol levels are reached after intravenous ethanol administration and lowest after oral ethanol ingestion after NBS application $(p=0.0356)$. Peak ethanol levels are also significantly different if oral ethanol intake following MCP application is compared with that after NBS administration $(p=0.0233)$. The time point of peak ethanol concentration is delayed when ethanol is administered orally after NBS application compared with the control group without any medication $(p=0.0371)$ and compared with the MCP group ( $\mathrm{p}=0.0356)$.

As shown in table 2, the speed of GE was significantly increased with MCP $(p=0.0006)$ and decreased with NBS ( $p=0.0001)$. No difference in the speed of GE was noted between men and women. Figure 7 correlates FPM of ethanol with the activity of gastric ADH of the antrum (A), the body (B), and both (C), expressed as the mean of the two values. No significant correlation was found. In addition, $\mathrm{ADH}$ activity in men was similar to that in women (antrum: 2.54 (0.81) v 2.34 (1.98), $\mathrm{p}=$ 0.8610 ; body: 5.13 (1.12) $v 4.39$ (1.96), $\mathrm{p}=$ 0.8722; mean of antrum and body: 3.94 (1.07) v $3.18(0.75), \mathrm{p}=0.7944)$. Genotyping showed $\mathrm{ADH}_{3}{ }^{1} / \mathrm{ADH}_{3}{ }^{1}$ in three subjects, $\mathrm{ADH}_{3}{ }^{1} / \mathrm{ADH}_{3}{ }^{2}$ in eight subjects, and $\mathrm{ADH}_{3}{ }^{2} / \mathrm{ADH}_{3}{ }^{2}$ in another three subjects. Although the numbers are too low to evaluate them statistically, the three volunteers with $\mathrm{ADH}_{3}{ }^{1} / \mathrm{ADH}_{3}{ }^{1}$ had a FPM of 19.6 (7.3)\% and an $\mathrm{ADH}$ activity of 6.00 (1.48) 


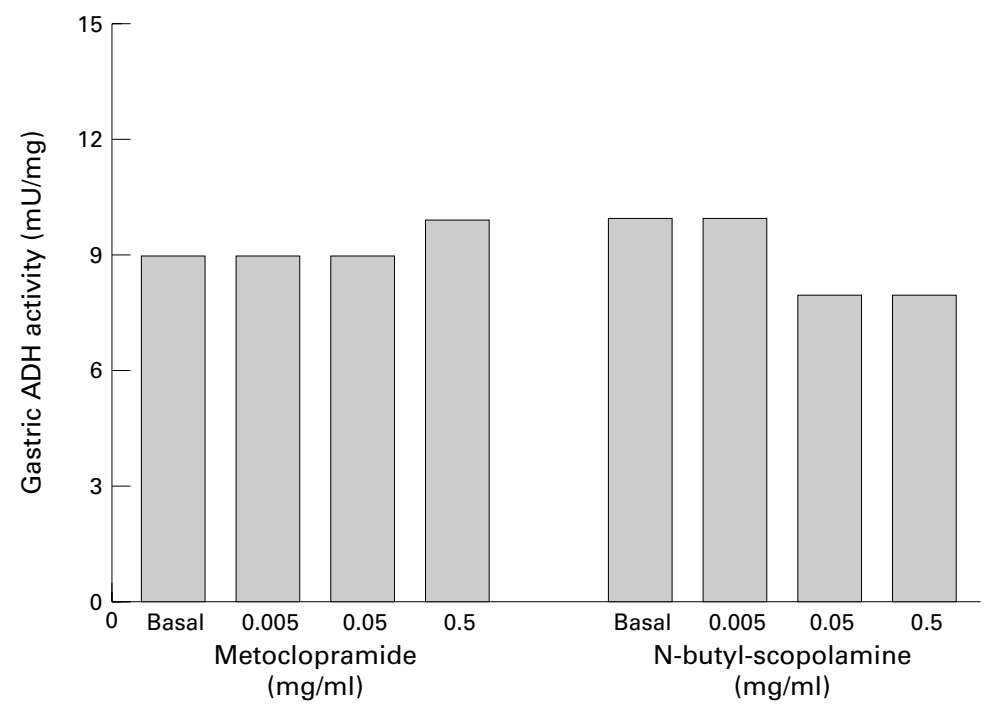

Figure 8 In vitro effect of metoclopramide and $N$-butylscopolamine on gastric alcohol dehydrogenase $(A D H)$ activity.

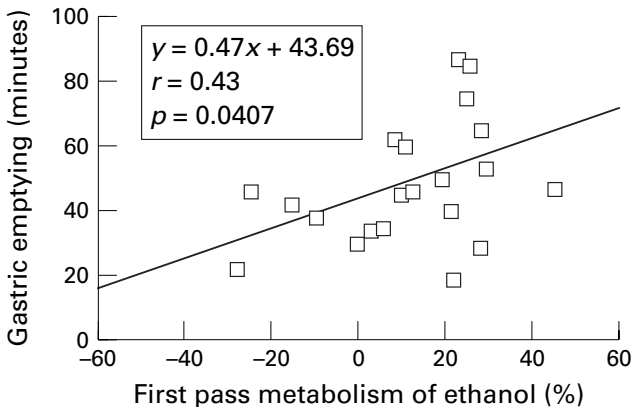

Figure 9 Correlation of first pass metabolism of alcohol and the speed of gastric emptying $(n=23)$.

$\mathrm{nmol} / \mathrm{min}$ per $\mathrm{mg}$ protein, the eight volunteers with $\mathrm{ADH}_{3}{ }^{1} / \mathrm{ADH}_{3}{ }^{2}$ an FPM of 5.0 (7.9)\% and an $\mathrm{ADH}$ activity of $3.11(1.32) \mathrm{nmol} / \mathrm{min}$ per mg protein, and the three volunteers with $\mathrm{ADH}_{3}{ }^{2} / \mathrm{ADH}_{3}{ }^{2}$ an FPM of $-1.8(25.4) \%$ and an $\mathrm{ADH}$ activity of $2.42(2.04) \mathrm{nmol} / \mathrm{min}$ per mg protein. Figure 8 shows the effect of MCP and NBS on ADH activity in gastric tissue in vitro, showing no effect of those drugs on gastric $\mathrm{ADH}$ activity. Figure 9 correlates the speed of GE with FPM of ethanol with a significant correlation of $\mathrm{p}=0.0407$.

\section{Discussion}

The data presented here show clearly that GE time strikingly influences FPM and systemic bioavailability of alcohol in man. As already shown in a previous study, ${ }^{24}$ a significant correlation between the speed of GE and FPM of ethanol was noted. In a recent investigation by Amir et $a l,{ }^{18}$ a significant correlation between GE and FPM of ethanol has also been shown when the $\mathrm{H}_{2}$ receptor antagonist ranitidine was administered. Because of the stimulating effect of ranitidine on gastric motility, increased serum ethanol concentrations have been observed after oral intake in the presence of this drug.

The drugs administered in the present study (MCP and NBS), which led to significant changes in FPM of ethanol, significantly altered gastric motility and influenced GE time without having any effect on gastric $\mathrm{ADH}$ activity in vitro. The fact that MCP increases ${ }^{36}$ and anticholinergic drugs decrease alcohol absorption ${ }^{37}$ has been used in the present work to investigate whether a change in GE time affects gastric alcohol metabolism, hepatic alcohol metabolism, or both. Indeed, a delayed GE time leads to prolonged exposure of alcohol to gastric $\mathrm{ADH}$ and thus results in increased gastric ethanol metabolism. On the other hand, rapid GE of a small dose of ethanol may change the ability of the liver to remove ethanol and diminish hepatic FPM. ${ }^{9}$ A delayed GE, however, would delay the delivery of ethanol into the small intestine. A lower rate of ethanol absorption from the small intestine could optimise hepatic metabolism of absorbed ethanol and could contribute to an increased hepatic FPM of alcohol. ${ }^{8-10}$ Thus the rate of GE probably influences both gastric and hepatic FPM of ethanol and therefore seems to be an important modulator of the FPM of alcohol.

GE has been shown to be modified in normal subjects by many different factors. ${ }^{38}$ According to Parkman et al, ${ }^{39} \mathrm{GE}$ is affected by age, gender, menopausal status, and phase of menstrual cycle. It is generally slower in elderly subjects ${ }^{40}{ }^{41}$, and may be affected by hormonal status in women. ${ }^{39}{ }^{42}$ Endogenous or exogenous female sex hormones are thought to be responsible for this effect on GE, which has been shown recently in rats. ${ }^{43}$ In addition, there are also reports that gastric motility is affected by heavy cigarette smoking ${ }^{44}$ and by different kinds of stress. ${ }^{45}$ Finally, chronic liver disease and portal hypertension are associated with delayed GE. ${ }^{46}$ Thus, if the FPM of ethanol is compared between groups, the speed of GE should also be measured and taken into consideration.

In a recent study by Ammon et al, ${ }^{47}$ FPM of ethanol was determined in six men and six women after a standardised meal using deuterated ethanol administration together with the administration of unlabelled ethanol at a dose of $0.3 \mathrm{~g} / \mathrm{kg}$ body weight. The authors found a total FPM of ethanol of $9.1 \%$ in men and $8.4 \%$ in women and that FPM of ethanol was primarily of gastric origin. These data are in the same range as our results showing an FPM of ethanol of $6.5 \%$ for all subjects studied. It is noteworthy that FPM of ethanol varies with regard to the oral ethanol dose used and to the time of GE. Thus low doses of ethanol such as $0.150 \mathrm{~g} / \mathrm{kg}$ body weight as used by DiPadova et $a l^{27}$ or $0.225 \mathrm{~g} / \mathrm{kg}$ body weight as used in our study, together with the administration of a light meal resulting in delayed GE, increase FPM of ethanol in general, whereas higher doses of alcohol administered into an empty stomach with enhanced GE decrease FPM of ethanol.

No gender effect was noted for FPM of ethanol or gastric ADH activity. This is in disagreement with data from our own laboratory ${ }^{5}$ and with the results of Frezza et al. ${ }^{3}$ It is, however, in accordance with the data of Ammon et $a l .{ }^{47}$ We have recently found higher blood ethanol concentrations in women than in men in a population of elderly patients with and without 
atrophic gastritis..$^{24}$ In this study, it seemed that GE was delayed in men compared with women and could therefore explain the finding of higher ethanol concentrations in women, which has also previously been reported. ${ }^{3}$ The gender effect on gastric $\mathrm{ADH}$ activity may depend, among other things, on the ethanol concentration used. Gender effects have been described when ethanol concentrations of 200 $\mathrm{mM}$ and above have been used, ${ }^{3513}$ whereas no such effects were observed with ethanol concentrations of between 16 and 100 $\mathrm{mM},{ }^{12526}$ as also shown here. In addition, it is noteworthy that other factors, such as gastric mucosal injury (inflammation or atrophy) and/or the presence or absence of $\sigma-\mathrm{ADH}$ and the polymorphism of $\mathrm{ADH}_{3}$, affect gastric $\mathrm{ADH}$ activity so much that gender effects cannot be detected. ${ }^{2122}{ }^{26}$ Interestingly, in this context it was found that the interval from the end of oral alcohol intake to the time of peak blood alcohol concentration was highly variable, being 57 (32) minutes in men and 42 (22) minutes in women after the administration of $0.4-1.6 \mathrm{~g}$ ethanol per kg body weight. ${ }^{38}$ This again points to greater alcohol absorption in women than men possibly because of enhanced GE. Another factor that may increase blood ethanol concentrations in women compared with men, also not studied here, is the gender difference in body water. ${ }^{48}$ In any case, these data underline the necessity of controlling GE time, in addition to other factors including gastric ADH activity, when FPM of ethanol is investigated, and the variability of the factors discussed above may be responsible for some of the discrepancies reported in the literature.

Although it has been reported that gastric $\mathrm{ADH}$ activity correlates with FPM of ethanol, ${ }^{3}$ this could not be confirmed in the present investigation, which may be due to the small number of volunteers but also to the fact that GE time, at least in our study, has a striking modulatory effect on FPM by the mechanisms discussed above. Moreno et al emphasised that polymorphism of $\mathrm{ADH}_{3}$ modulates $\mathrm{ADH}$ activity. Those with $\mathrm{ADH}_{3}{ }^{1-1}$ had a higher ADH activity than those with $\mathrm{ADH}_{3}^{2-2}$ measured at $100 \mathrm{mM}$ ethanol concentration. Although the numbers are small, it is of interest that those volunteers genotyped as $\mathrm{ADH}_{3}{ }^{1} / \mathrm{ADH}_{3}{ }^{1}$ had a higher FPM of ethanol than those with $\mathrm{ADH}_{3}{ }^{1}$ / $\mathrm{ADH}_{3}{ }^{2}$ and $\mathrm{ADH}_{3}{ }^{2} / \mathrm{ADH}_{3}{ }^{2}$.

In the present study, the AUC method to calculate FPM of ethanol was used, as, in our opinion and as previously pointed out by Ammon et $a l^{47}$ the integrated MichaelisMenten equation to estimate FPM is subject to the error introduced by the need to determine $\mathrm{C}_{\mathrm{o}}$ (extrapolated zero time concentration of alcohol, which is subject to substantial error), $\mathrm{K}_{\mathrm{m}}$, and $\mathrm{V}_{\max }$. It has been shown that $\mathrm{V}_{\max }$ and $\mathrm{K}_{\mathrm{m}}$ vary considerably among individuals. $\mathrm{K}_{\mathrm{m}}$ was also found to vary by up to fourfold in the same individual tested within a week, and $\mathrm{V}_{\max }$ varied by as much as $30 \%$. $^{49}$

In conclusion, various factors seem to be relevant in the gastric and hepatic FPM of ethanol. Among those, GE time is probably an important modulator of both gastric and hepatic FPM of ethanol. Delayed GE leads to increased, and accelerated GE to decreased, FPM of ethanol. Thus it is difficult or even impossible to draw conclusions from first-pass experiments in man with respect to mechanisms without knowing the GE time and taking that into consideration.

This work was supported by a grant from the European Community (Biomed, BMH1-CT93-1601) and by grants from the EMDO Stiftung (Zürich, Switzerland), the Theodor and Ida Herzog-Egli-Stiftung (Zürich, Switzerland), the Janggen-PöhnStiftung (St Gallen, Switzerland), and the Swiss Society of Gastroenterology and Hepatology (Bern, Switzerland) to CMO.

1 Yin S-J, Liao C-S, Wu C-W, et al. Human stomach alcohol and aldehyde dehydrogenases: comparison of expression pattern and activities in alimentary tract. Gastroenterology 1997;112:766-75.

2 Moreno A, Parés A, Ortiz J, et al. Alcohol dehydrogenase from human stomach: variability in normal mucosa and Alcohol Alcohol 1994;29:663-71.

3 Frezza M, DiPadova C, Pozzato G, et al. High blood alcohol Frezza M, DiPadova C, Pozzato G, et al. High blood alcohol
levels in women. The role of decreased gastric alcohol levels in women. The role of decreased gastric alcohol
dehydrogenase activity and first-pass metabolism. $N$ Engl f Med 1990;322;95-9.

4 Moreno A, Parés X. Purification and characterization of a new alcohol dehydrogenase from human stomach. $\mathcal{F}$ Biol Chem 1991;266:1128-33.

5 Seitz HK, Egerer G, Simanowski UA, et al. Human gastric alcohol dehydrogenase activity: effect of age, sex, and alcoholism. Gut 1993;34:1433-7.

6 Dohmen K, Baraona E, Ishibashi H, et al. Ethnic differences in gastric $\sigma$-alcohol dehydrogenase activity and ethanol first-pass metabolism. Alcohol Clin Exp Res 1996;20:1569-

7 Smith T, DeMaster EG, Furne JK, et al. First-pass gastric mucosal metabolism of ethanol is negligible in the rat. $\mathcal{F}$ Clin Invest 1992;89:1801-6.

8 Levitt MD, Levitt DG. The critical role of the rate of ethanol absorption in the interpretation of studies purporting to demonstrate gastric metabolism of ethanol. F Pharm Exp Ther 1994;269:297-304.

9 Levitt MD, Levitt DG, Furne J, et al. Can the liver account for first-pass metabolism of ethanol in the rat? Am $\mathcal{F}$ Physiol
font 1994;267:G452-7.

10 Levitt MD. Antagonist: the case against first-pass metabolism of ethanol in the stomach. F Lab Clin Med 1994;123:28-31.

11 Seitz HK, Egerer G, Simanowski UA. High blood alcohol levels in women. [Letter] N Engl f Med 1990;323:58.

12 Harada S, Okubo T. Investigation of alcohol dehydrogenase isozymes of biopsy gastric mucosa in Japanese. Alcohol Alcohol 1993;28:59-62.

13 Haber PS, Gentry RT, Mak KM, et al. Metabolism of alcohol by human gastric cells: relation to first-pass metabolism. Gastroenterology 1996;11:863-70.

14 Seitz HK, Veith S, Czygan P, et al. In vivo interactions between $\mathrm{H}_{2}$-receptor antagonists and ethanol metabolism between $\mathrm{H}_{2}$-receptor antagonists and ethanol
in man and in rats. Hepatology $1984 ; 4: 1231-4$.

15 Seitz HK, Simanowski UA, Egerer G, et al. Human gastric alcohol dehydrogenase: in vitro characteristics and effect of alcohol dehydrogenase: in vitro chas
cimetidine. Digestion 1992;51:80-5.

16 Caballeria J, Baraona E, Rodamilans $\mathrm{M}$, et al. Effects of cimetidine on gastric alcohol dehydrogenase activity and blood ethanol levels. Gastroenterology 1989;96:388-92.

17 DiPadova C, Roine R, Frezza M, et al. Effects of ranitidine on blood alcohol levels after ethanol ingestion: comparison with other $\mathrm{H}_{2}$-receptor antagonists. FAMA 1992;267:83-6.

18 Amir I, Anwar N, Baraona E, et al. Ranitidine increases the bioavailability of imbibed alcohol by accelerating gastric emptying. Life Science 1996;58:511-18.

19 Roine RP, Gentry RT, Lim RT, et al. Effect of concentration of ingested ethanol on blood alcohol levels. Alcohol Clin Exp Res 1991;15:734-8.

20 Roine R, Hernández-Munoz R, Baraona E, et al. Effect of omeprazole on gastric first-pass metabolism of ethanol. Dig

21 Salmela KS, Salaspuro M, Gentry RT, et al. Helicobacter infection and gastric ethanol metabolism. Alcohol Clin Exp Res 1994;18:1294-9.

22 Thuluvath P, Wonjo KJ, Yardley JH, et al. Effect of Helicobacter pylori infection and gastritis on gastric alcohol dehydrogenase activity. Alcohol Clin Exp Res 1994;18:795-8.

23 Gupta AM, Baraona E, Lieber CS. Significant increase of blood alcohol by cimetidine after repetitive drinking of small alcohol doses. Alcohol Clin Exp Res 1995;19:1083-7.

24 Pedrosa MC, Russell RM, Saltzman JR, et al. Gastric emptying modulates first pass metabolism of ethanol in elderly subjects with and without atrophic gastritis. Scand 7 Gastroenterol 1996;31:671-7.

25 Osswald BR, Simanowski UA, Arce L, et al. Helicobacter pylori infection decreases first pass metabolism of ethanol in man. [Abstract] Gastroenterology 1994;106:A956.

in man. [Abstract] Gastroenterology 1994;106: A956.
26 Brown AS, Fiatarone JR, Wood P, et al. The effect of gastritis on human gastric alcohol dehydrogenase activity and ethanol metabolism. Aliment Pharmacol Ther 1995;9:5761 . 
27 DiPadova C, Worner TM, Julkunen RJK, et al. Effects of fasting and chronic alcohol consumption on the first-pass metabolism of ethanol. Gastroenterology 1987

28 Caballeria J, Frezza M, Hernandez-Munoz R, et al. Gastric origins of the first-pass metabolism of ethanol in humans: effect of gastrectomy. Gastroenterology 1989;97:1205-9.

29 Bucher T, Redeteski H. Eine spezifische photometrische Bestimmung von Aethylalkohol auf fermentativem Wege.
Klin Wochenschr 1951;29:615.

30 Bolondi L, Bortolotti M, Santi V, et al. Measurement of gastric emptying time by real-time ultrasonography. Gastroenterology 1985;89:752-9.

31 Wedmann B, SchaffsteinJ, Wegener $M$, et al. Sonographische Erfassung der Magenentleerung: Reliabilität und Validität der Antrumflächenmethode für Flüssigkeiten. $Z$ Gastroenterol 1990;28:448-52.

32 Lowry OH, Rosebrough NJ, Farr AL, et al. Protein measurement with the Folin phenol reagent. $\mathcal{F}$ Biol Chem 1951;193:265-75.

33 Coutelle C, Ward PJ, Fleury B, et al. Laryngeal and oropharyngeal cancer, and alcohol dehydrogenase 3 and glutath-
ione S-transferase M1 polymorphisms. Hum Genet 1997; ione S-tran

34 Groppi A, Begueret J, Iron A. Improved methods for genotype determination of human alcohol dehydrogenase $(\mathrm{ADH})$ at $\mathrm{ADH} 2$ and $\mathrm{ADH} 3$ loci by using polymerase chain reaction-directed mutagenesis. Clin Chem 1990;36 1765-8.

35 Price AB. The Sydney System: histological division. $f$ Gastroenterol Hepatol 1991;6:209-22.

36 Gibbons DO, Lant AF. Effect of intravenous and oral propantheline and metoclopramide on ethanol absorption. Clin Pharmacol Ther 1975;17:578-84.

37 Hall RC, Brown D, Carter R, et al. The effect of desmethylimipramine on the absorption of alcohol and paracetamol. Post Grad Med f 1976;52:139-42.
38 Holt S. Observations on the relation between alcohol absorption and the rate of gastric emptying. Can Med Assoc f 1981;124:267-77.

39 Parkman HP, Harris AD, Miller MA, et al. Influence of age, gender, and menstrual cycle on the normal electrogastrogram. Am f Gastroenterol 1996;91:127-33.

40 Horowitz M, Maddern GJ, Chatterton BE, et al. Changes in gastric emptying rates with age. Clin Sci 1984;67:213-18.

41 Moore HG, Tweedy C, Christian PE, et al. Effect of age on gastric emtying of liquid-solid meals in man. Dig Dis Sci 1983;28:340-4.

42 Gill RC, Murphy PD, Hooper HR, et al. Effect of the menstrual cycle on gastric emptying. Digestion 1987;36:168-74.

43 Chen TS, Doong ML, Chang FY, et al. Effects of sex steroid hormones on gastric emptying and gastrointestinal transit in rats. Am f Physiol 1995;268:G171-8.

44 Scott AM, Kellow JE, Shuter B, et al. Effects of cigarette smoking on solid and liquid intragastric distribution and gastric emptying. Gastroenterology 1993;104:410-16.

45 Marzio L, Formica P, Fabiani F, et al. Influence of physical activity on gastric emptying of liquids in normal human subjects. Am f Gastroenterol 1991;86:1433-6.

46 Galati JS, Holdeman KP, Dalrymple GV, et al. Delayed gastric emptying of both the liquid and solid components of a meal in chronic liver disease. Am 7 Gastroenterol 1994;89; 708-11.

47 Ammon E, Schäfer C, Hoffmann U, et al. Disposition and first pass metabolism of ethanol in humans: is it gastric or hepatic and does it depend on gender? Clin Pharmacol Ther 1996;59:503-13.

48 Marshall AW, Kingstone D, Boss M, et al. Ethanol elimination in males and females: relationship to menstrual cycle and body composition. Hepatology 1983;3:701-6.

49 Crabb DW. First pass metabolism of ethanol: gastric or hepatic, mountain or molehill. Hepatology 1997;25:1292-4. 